\title{
Reflection on Non-English Major Translation Teaching in Colleges and Universities in the Era of Big Data
}

\author{
Ying Li \\ School of Foreign Languages, Hubei Engineering University, Xiaogan, Hubei, 432000
}

Keywords: The Era of Big Data, Colleges and Universities, Non-English Majors, Translation Teaching

\begin{abstract}
With the continuous development of China's information technology, Internet plus technology has been widely used as a form of big data technology, which has effectively promoted the development of the industry, laying a solid foundation for enhancing China's data analysis and application ability. This paper reflects on the innovation of translation teaching in non-English major universities in the era of big data in hope of promoting the healthy development of English teaching in Chinese universities.
\end{abstract}

\section{Introduction}

With the development of new curriculum reform in China, teachers in the era of big data, constantly thinking of English teaching innovation strategy, in order to improve the comprehensive quality of students to lay the foundation. The practice of translation teaching innovation path of non-ordinary colleges and universities, should be different from the translation teaching for English majors on the translation characteristics, application, teaching pertinence, make students' English ability, which can meet the demand of future employment, to enhance their employment competitiveness, promote college English professional translation teaching quality [1-2]. For this reason, teachers should be based on the era of large data, and think about the strategy of integration of non-English major translation teaching in colleges and universities to improve the effectiveness of education.

\section{Research Background of Non-English Major Translation Teaching Innovation in the Era of Big Data}

Big data era with the rapid development of China's Internet technology, through Internet analysis extensive, comprehensive, systematic support for large data, the analysis of our data gradually get rid of stochastic analysis of constraints, so that our data analysis, in the use of cloud technology, cloud storage, sensing technology, distributed processing technology based on the form of Internet plus technology etc. It can effectively improve the effectiveness of the analysis, and give the analysis data "four $\mathrm{V}$ attributes", that is, fast, large capacity, high value and many kinds of application advantages [3]. In the era of big data, information in all areas of society is expanding and colliding, changing people's cognitive forms and understanding habits of established concepts, giving social development boundless vitality.

In order to be able to keep abreast of the new era, our education should cultivate innovative talents who advance with the times and who have excellent comprehensive qualities. Teachers should recognize the profound impact of big data era on education, and constantly think about ways and means to flexibly apply big data and other information technologies, and explore effective ways for educational innovation [4]. With the rich and diverse educational resources in the era of large data, the content of non - English major translation education in colleges and universities is fully realized. It can satisfy students' Personalized English learning needs, stimulate students' interest in English translation and learning, enrich English teachers' translation teaching methods, improve their English translation ability, and achieve the goal of improving the comprehensive quality of translation teaching in non-English Majors in universities. 
The era of big data, the background of translation teaching research and analysis of non-ordinary colleges and universities, college English translation teaching to scientific and effective, to cater to the era of big data, clear its positive influence on college English translation teaching for English majors, English translation education innovation strategy. In the era of large data, information technology is an effective method to improve the comprehensive quality of translation teaching. In order to make teaching innovation more effective in the era of big data, English teachers should think deeply about the implementation of translation teaching in non-English Majors in colleges and universities, so as to lay the foundation for analyzing the teaching innovation mode.

\section{The Positive Impact of the Big Data Age on the Teaching of Non-English Major Translation in Colleges and Universities}

(1) It is beneficial to enrich the teaching content of non - English major translation in colleges and universities. The reason why colleges and universities open English translation teaching is to improve students' comprehensive quality, so that students can better cope with the pressure of employment. However, nowadays, non-English Majors in colleges and universities focus on the teaching of English grammar and their applications. The content of translation teaching is weak, and the length of English translation teaching is small, which affects the effective promotion of non-English Majors' English translation ability [5]. Through information technology in the era of big data, teachers can flexibly absorb teaching resources according to teaching needs, enrich English translation teaching contents, enrich the translation teaching contents of non-English Majors in colleges and universities, and lay the foundation for improving the comprehensive quality of teaching.

(2) It is helpful to arouse the students' interest in learning. In the past, the translation teaching content of non-English Majors in colleges and universities is based on book knowledge, which is divorced from students' learning needs. It can not stimulate students' interest in English translation and learning, reduce the interaction efficiency between teachers and students in English translation teaching, and affect the comprehensive quality of translation teaching. Through the analysis technology in the era of big data, teachers can flexibly select the content of translation teaching that accords with students' learning psychology, so that teaching content is different from the form of book knowledge expression, which can enhance students' interest in independent analysis and stimulate students' enthusiasm in English translation learning. In the teaching content of English translation that meets the needs of their own learning, we should realize the pleasure of English translation and achieve positive interaction between teachers and students, so as to improve the effectiveness of English translation teaching [6].

(3) It is beneficial to improve the effectiveness of English translation teaching. Big data analysis technology has breadth and depth. It can combine analysis needs, carry out comprehensive and efficient data analysis, ensure that the analysis conclusion has high application value, and is consistent with the development needs of things. Based on this, college English teachers should be clear about the purpose of English translation teaching for non-English majors, so as to improve their comprehensive quality and enhance their ability to cope with employment competition. Therefore, the translation learning of non-English majors should be more targeted, accord with the individual needs of different industries, and implement teaching contents, so as to achieve the purpose of training students' comprehensive quality [7-8]. For example, when conducting translation teaching for marketing majors, teachers should combine with their industry characteristics such as finance, trade and business services in the future. Based on big data analysis technology, we need to analyze the teaching contents of English translation for students of this major. Based on this, we build effective English classroom, ensure English translation teaching content, accord with students' professional development needs, and give English translation teaching effectiveness.

By analyzing the influence of the age of big data on translation teaching practice of non-English Majors in colleges and universities, we can see that in the era of big data, effective atmosphere for translation teaching is well established [9]. Therefore, English teachers should uphold 
self-reflection. An in-depth analysis of the current situation of non-English major translation teaching in colleges and universities is intended to provide a path for the innovation and application of English translation teaching methods in the era of large data.

\section{Current Situation of Non-English Major Translation Teaching in Colleges and Universities}

(1) The subject of teaching is blurred. In the era of big data, teachers in order to make effective use of information technology and other innovative teaching modes appear the following situations, which affect the effectiveness of English translation teaching. First, teachers rely too much on the information based teaching mode in the era of big data. In order to make the content of non-English majors translation teaching fulfillment, teachers blindly use of the Internet on the educational resources, focus only on the rich, but ignore the internal relationship and translation teaching, so that students in the English teaching process, such as watching the "lantern", immersed in the translation of various teaching content, but I do not know the study of translation on translation teaching effectiveness weakened under the era of big data [10]. Divided by translation teaching knowledge as the subject in class, teachers are in their teaching subjects, the teaching mode of oral teaching that inspires true understanding within the students' learning initiative, amblyopia, reduce the quality of English translation teaching, the teaching content of informatization under the era of big data, the loss of the value of teaching.

(2) Teaching specialties are not strong. The reason for the translation teaching for non-English majors is to analyze the innovation strategy, teaching mode and professional English translation teaching mode to distinguish, the comprehensive quality of college students is more effective, which can effectively enhance the ability to adapt to society, in order to improve the employment rate of college foundation [11]. However, in the innovation process of non-professional English translation teaching in colleges and universities, there are still too many systems and lack of pertinence, which makes students' English translation teaching fail to highlight the needs of non-professional education and reduce the effectiveness of English translation teaching.

(3) The mode of teaching innovation is not used properly. With the development of the new curriculum reform in China, in the era of big data, the innovation of teaching mode is in full bloom, laying the foundation for meeting the needs of individualized education. In order to make the college English translation teaching for English majors are more innovative, some teachers use "empiricism", copy the successful experience in translation teaching for non-English Majors for the poor, and not the teaching content, the learning needs of students and the teaching goal resonate. This kind of blind teaching innovation is more common in the course of English Teaching in ordinary colleges and universities, which has become an intrinsic factor restricting the effective improvement of the teaching level [12].

Through to our country college English translation teaching for non-professional status analysis shows that most English teachers are aware of the necessity of English teaching innovation in the era of big data, there are innovative teaching methods to implement the reality of the situation is improper, which can not effectively enhance the effectiveness of translation teaching for non-English majors. Based on this, in order to make the translation teaching of non-English Majors in colleges and universities more effective, it is particularly important to think about the effective innovation strategy of teaching mode in the era of big data.

\section{Reflection on the Innovation of Non-English Major Translation Teaching in Colleges and Universities in the Era of Big Data}

(1) Teachers should be rich in the spirit of the times to improve their teaching comprehensive level. In the era of big data, the constraints of traditional educational concepts and teaching methods are obvious, which can not effectively respond to the needs of teaching practice, and affect the teaching innovation effect of non-English majors. As an important person to effectively practice education mode and teaching idea, English teachers should keep pace with the times and constantly improve their teaching comprehensive ability. The new teaching mode and teaching idea into the era 
of big data given, providing innovative path for its access to the target class, translation teaching for non-English majors, and the new teaching mode is the organic integration of good organic fusion form of innovative teaching mode and traditional education, improve the teaching quality of the comprehensive. For example, teachers should make use of their spare time to learn the information teaching software in the era of big data, enhance the ability to flexibly grasp the new teaching technology, explore the form of teaching innovation, and ensure the effective combination of teaching content and new educational mode. At the same time, universities should set up a "big data era of educational innovation incentive mechanism", through the effective incentive mechanism, encourage teachers to carry out teaching practice innovation, promote the innovation of teacher education enthusiasm, teacher education and training innovative self-confidence, give more access to education innovation path under the era of big data, in order to improve college English professional translation teaching the quality of foundation.

(2) Using the information teaching method in the era of big data, it is flexible to enrich the form of translation teaching content. In order to make the teaching mode more effective in the era of big data, teachers, based on textbooks, analyze the forms of translation teaching content in the era of big data, and ensure that teaching innovation is consistent with the learning needs of non-English majors. For example, teachers can use large data technology to analyze the weak links of non English major translation teaching in colleges and universities. Through the analysis, it is clear that there is a lack of basic teaching for the English translation of non - English majors, which weakens the deep teaching of translation skills. Usually, only after class homework is used to guide students to do self-translation exercises. Most teachers take a lot of exercises after class, and do not explain the translation skills thoroughly, which will affect the effectiveness of translation teaching for non-English majors. Based on this, the English teachers should be combined with the conclusion of big data analysis, the use of information technology teaching resources, the search with the effective resources of translation teaching for English Majors of non-college English translation teaching, enrich the content, to consolidate the non-English Majors' basic translation skills [13]. For example, teachers can use multimedia technology to play the popular film "great law" for students to interpret the translation of Chinese English translation. The film dialogue brief, concise, more suitable for the teaching of English translation, such as "I want someone to tell me, why I can do, have their own fear the power of the translation, because the translation for" I also want someone to tell me why I can do this and have the power to fear myself". Teachers can focus on the translation skills of attributive clauses, and guide students to make sentences training by using this sentence pattern, so as to cultivate students' English Chinese translation ability and achieve the purpose of improving non English Majors' English translation ability.

(3) Using large data to improve the pertinence of non-English translation teaching. Through the large data system analysis, we can effectively understand the needs of English translation education for students of different specialties. With the help of information technology in the era of big data, we need to collect professional targeted translation teaching contents, create school-based textbooks, enhance the effectiveness of translation teaching in non-English Majors in universities, and lay the foundation for improving the comprehensive level of college education. For example, in terms of medical students, teachers in English teaching, the students from the professional perspective, expand the pharmaceutical, medical equipment, disease, treatment methods and translation of English education, enhance students' English ability professional, lay the foundation for the comprehensive literacy training for non-English majors.

In the era of large data, the teaching of non - English Majors in colleges and universities is more likely to be taught, and the mode of teaching innovation is not limited. As long as we meet the needs of teaching and meet the needs of students' individualized growth, we can effectively cultivate students' comprehensive literacy, which can be applied in the innovative practice of non-professional students in English education. For this reason, English teachers should constantly improve their personal accomplishment, work hard to learn the ideas of advanced education and give new ideas to teaching. 


\section{Conclusions}

To sum up, in order to improve the comprehensive level of teaching, under the guidance of the new curriculum reform, China's education continues to carry out the information teaching mode in the era of big data, so as to lay the foundation for improving teaching quality. Based on this, college English teachers should constantly improve their educational innovation ability, flexibly apply the information based teaching mode, ensure that English translation teaching is in line with the needs of personalized growth of non-English majors, and achieve the purpose of improving the comprehensive level of English Teaching in colleges and universities.

\section{References}

[1] Ren C H, Pang D. Research on the Reform of the Teaching Mode of Ideological and Political Theory Education in Universities in the Era of Big Data [J]. Journal of Weinan Normal University, 2016.

[2] Cui L. Brief Analysis of Schools Enterprises Cooperation Teaching in Colleges and Universities in the Era of Big Data[C]// International Conference on Mechatronics, Computer and Education Informationization. 2016.

[3] Zhang T. A Study on the New Model of Precise Funding in Colleges and Universities in the Era of Big Data [J]. Guide of Science \& Education, 2017.

[4] Wang X L, Ren H L. Reflection on the Construction of Experimental Teaching Staff Team in Agricultural Colleges and Universities in the New Era [J]. Research \& Exploration in Laboratory, 2013.

[5] Xie Y, University G O. Research on the Security Governance of Colleges and Universities in the Era of Big Data [J]. Journal of Yunnan Open University, 2017.

[6] Bao J. Discussion on Colleges and Universities' Innovation Educational Mechanism in the Era of Mass Higher Education [J]. 2015.

[7] Peng J L. On Necessity of Traditional Culture Education Innovation in Colleges and Universities in the Era of Mobile Internet [J]. Journal of Hubei Correspondence University, 2015.

[8] Mao X. Study on the Curriculum Reform of Local Agricultural Colleges and Universities in the Era of Network Curriculum[C]// International Conference on Management Science and Innovative Education. 2016.

[9] Liu H, Wang F, Yang L X. On the college English research in the new erareflection [J]. Journal of Jiamusi Education Institute, 2012.

[10] He X. An Action Research on Improving Non-English Majors' English Writing by "Basic Sentence Pattern Translation Drills". [J]. English Language Teaching, 2015, 9(1):142.

[11] Pei Z. Classroom discourse in college English teaching of China: a pedagogic or natural mode? [J]. Journal of Multilingual \& Multicultural Development, 2015, 36(7):1-17.

[12] Sun C. Reflection on the Connotation of Innovative Education in Colleges and Universities and Cultivation of Innovative Talents [J]. 2015.

[13] Liu H, Zhao B Y. Reflection on the Construction of College Chinese Teaching Materials in Micro-era Context [J]. Journal of Huaihai Institute of Technology, 2012. 